\title{
Effect of aminophylline on brain tissue oxygenation in patients with chronic obstructive lung disease
}

\begin{abstract}
M Nishimura, A Suzuki, A Yoshioka, M Yamamoto, Y Akiyama, K Miyamoto, F Kishi, Y Kawakami
\end{abstract}

\begin{abstract}
Background It is known that theophylline reduces cerebral blood flow in humans. To quantitatively assess the possible adverse effect of theophylline on brain tissue oxygen tension $\left(\mathrm{PO}_{2}\right)$ due to decreased cerebral blood flow, two sets of experiments were conducted in mildly hypoxaemic patients with chronic obstructive lung disease.
\end{abstract}

Methods Firstly, internal jugular venous $\mathrm{PO}_{2}\left(\mathrm{PjO}_{2}\right)$ was measured simultaneously with arterial and mixed venous blood $\mathrm{PO}_{2}\left(\mathrm{PaO}_{2}\right.$ and $\left.\mathrm{P}^{\mathrm{v}} \mathrm{O}_{2}\right)$ during right heart catheterisation in 10 subjects (mean $\mathrm{PaO}_{2} 73 \mathrm{~mm} \mathrm{Hg}$; conversion factor: $10 \mathrm{~mm} \mathrm{Hg}=1.33 \mathrm{kPa})$ ) before and after intravenous infusion of aminophylline (6 mg/kg). The $\mathrm{Pjo}_{2}$ and $\mathrm{P}_{\bar{v}} \mathrm{O}_{2}$ were considered to reflect the average tissue $\mathrm{PO}_{2}$ for the brain and for the whole body respectively. Secondly, the relation between $\mathrm{PaO}_{2}$ and $\mathrm{PjO}_{2}$ over a wide range, with the $\mathbf{P a C O}_{2}$ similar to that in the first study, was investigated in a different group of 12 subjects by stepwise changes in inspiratory gas composition.

Results The mean $\mathrm{PjO}_{2}$ decreased by as much as $6 \mathrm{~mm} \mathrm{Hg} 15$ minutes after an infusion of aminophylline, whereas $\mathrm{PaO}_{2}$ stayed at the same level and $P \bar{v} O_{2}$ showed only a small decrease. The low $\mathrm{PjO}_{2}$ value of 29 (SD 6) $\mathrm{mm} \mathrm{Hg}$ with aminophylline in the first study was similar to the $\mathrm{Pjo}_{2}$ value of 30 (2) $\mathrm{mm} \mathrm{Hg}$ obtained during severe hypoxia $\left(\mathrm{PaO}_{2} 45 \mathrm{~mm} \mathrm{Hg}\right)$ in the second study. The coefficient of oxygen delivery for the brain decreased by $29 \%$ with aminophylline treatment, but did not change significantly during severe hypoxic challenge.

Conclusions These data suggest that an infusion of aminophylline lowers brain tissue $\mathrm{PO}_{2}$ appreciably when given to mildly hypoxaemic patients with chronic obstructive lung disease.

(Thorax 1992;47:1025-1029)

Theophylline, a methylxanthine, is widely used in the treatment of asthmatic patients and those with chronic obstructive lung disease. Recent studies have raised the possibility that theophylline may induce behavioural abnormalities and impair school performance in children. ${ }^{12}$ Some patients with chronic obstructive lung disease are reported to have impaired neuropsychological function, which is, at least in part, due to chronic mild or moderate hypoxia. $^{34}$

Because theophylline, which is an adenosine receptor antagonist, has been shown to reduce cerebral blood flow in humans, ${ }^{5-8}$ including patients with chronic obstructive lung disease, ${ }^{9}$ we considered it important to examine how it influences the oxygenation of brain tissue. A decrease in cerebral blood flow combined with a possible increase in local brain metabolism may induce a substantial decrease in brain tissue oxygenation, particularly when the drug is administered to hypoxaemic subjects. In the first study we measured internal jugular venous blood gases simultaneously with arterial and mixed venous blood gases during right heart catheterisation in patients with stable chronic obstructive lung disease before and after an aminophylline infusion. The partial pressure of oxygen $\left(\mathrm{PO}_{2}\right)$ in internal jugular venous blood $\left(\mathrm{PjO}_{2}\right)$ is thought to be one factor influencing brain tissue $\mathrm{PO}_{2}$. In a second study with another group of patients, we established the relation between arterial $\mathrm{PO}_{2}\left(\mathrm{PaO}_{2}\right)$ and $\mathrm{PjO}_{2}$ over a wide range by stepwise changes in inspiratory gas composition to confirm the differential effect of aminophylline on $\mathrm{PaO}_{2}$ and $\mathrm{PjO}_{2}$ obtained in the first experiment.

\section{Methods}

Groups of 10 and 12 male patients with chronic obstructive pulmonary disease participated in the first and second study respectively. All the patients were given written information about the purpose and risks of the study and gave informed consent. The protocol was approved by the ethics committee of the Hokkaido University School of Medicine. The diagnosis of chronic obstructive lung disease was made on the basis of clinical history, physical findings, chest radiographs, and tests of pulmonary function. The minimum requirement for inclusion in the study was a forced expiratory volume in one second: forced vital capacity $\left(\mathrm{FEV}_{1} / \mathrm{FVC}\right)$ ratio of less than $70 \%$. Patients who had more than a $15 \%$ increase in $\mathrm{FEV}_{1}$ after inhaling orciprenaline $(10 \mathrm{mg} / 0.5 \mathrm{ml})$ were excluded from the study. Table 1 shows the data on the characteristics of patients and on pulmonary function. Data on pulmonary 
Table 1 Data on patient characteristics and pulmonary function

\begin{tabular}{|c|c|c|}
\hline & $\begin{array}{l}\text { Study } 1(n= \\
\text { Mean }(S D)\end{array}$ & $\begin{array}{l}\text { 9) Study } 2(n=12) \\
\text { Mean (SD) }\end{array}$ \\
\hline Age (y) & $62(12)$ & $59(13)$ \\
\hline Height (cm) & $162(6)$ & $162(7)$ \\
\hline Body weight (kg) & $51(7)$ & $55(9)$ \\
\hline VC (\% predicted $)$ & 70 (17) & $79(16)$ \\
\hline $\mathrm{FEV}_{1}(\mathrm{l})$ & $1.22(0.39)$ & $1.12(0.43)$ \\
\hline $\mathrm{FEV} / \mathrm{FVC}(\%)$ & $57(9)$ & $50(11)$ \\
\hline TLCO (\% predicted) & $49(20)$ & $69(37)$ \\
\hline
\end{tabular}

VC-vital capacity; FEV $_{1}$-forced expiratory volume in one second; TLCo-transfer factor (diffusion capacity) for carbon monoxide (single breath)

function were obtained from each subject no more than two weeks before the study during a period when the disease was clinically stable.

Before the study, catheters (Angiocath) were placed into the left brachial artery and the right internal jugular vein under local anaesthesia. The right internal jugular vein was punctured about $3 \mathrm{~cm}$ below the tip of the mastoid process at the posterior edge of the sternocleidomastoid muscle and the catheter was carefully advanced about $4 \mathrm{~cm}$ cephalad to reach a point as close as possible to the superior jugular bulb. Blood samples were taken at a rate slow enough to prevent drawing blood in a retrograde direction. There were no serious complications such as infection, haematoma, or thrombosis. Blood gases $\left(\mathrm{PO}_{2}\right.$ and $\left.\mathrm{PCO}_{2}\right)$ and $\mathrm{pH}$ were analysed with a blood gas analyser (type 1303, Instrumentation Laboratory) soon after sampling. Oxygen haemoglobin saturation was determined with a carbon monoxide oximeter (Model 282, Instrumentation Laboratory). Arterial blood pressure and the electocardiogram were monitored throughout the study.

For the first study, right heart catheterisation was performed before the procedures described. A Swan-Ganz catheter (Swan-Ganz model 93A-821H, 7F; American Edwards) was inserted transcutaneously through the left antecubital vein and advanced to the pulmonary wedge position guided by pressure tracings. Right atrial, right ventricular, pulmonary arterial, and pulmonary wedge pressures were monitored by a transducer (Gould-Statham P231ID; Gould Inc), and recorded on a multichannel recorder. Cardiac output was measured by means of a computerised thermodilution technique (Cardiac Output Computer, Nihon Kohden) with injection of $10 \mathrm{ml}$ of iced $5 \%$ glucose in water. Mixed venous blood samples were obtained from the main pulmonary artery. Oxygen content was calculated as:

$\left(1.34 \times \mathrm{Hb} \times \mathrm{So}_{2}\right)+\left(0.0031 \times \mathrm{Po}_{2}\right)$,

where $\mathrm{Hb}$ represents haemoglobin $(\mathrm{g} / \mathrm{dl}), \mathrm{So}_{2}$ oxygen haemoglobin saturation, and $\mathrm{Po}_{2}$ oxygen pressure. Oxygen supply in the tissues depends on both convective and diffusional transport processes. ${ }^{10}$ The first is located within the vascular system and can be expressed by the variable "oxygen transport," the product of blood flow and arterial oxygen content, or, if normalised for oxygen consumption $\left(\dot{\mathrm{Vo}}_{2}\right)$, by the coefficient of oxygen delivery. The coefficient of oxygen delivery for the whole body and for the brain can be conveniently calculated without direct measurement of blood flow and oxygen consumption. As oxygen consumption for the whole body is the product of cardiac output and the difference in oxygen content between arterial and mixed venous blood according to Fick's equation, the coefficient of oxygen delivery for the whole body can be calculated as arterial oxygen content divided by the difference in oxygen content between arterial and mixed venous blood as shown in the equation:

coefficient of oxygen delivery (whole body) body)

$$
=\text { cardiac output } \times \mathrm{CaO}_{2} / \dot{\mathrm{VO}}_{2} \text { (whole }
$$

$$
=\mathrm{CaO}_{2} /\left(\mathrm{CaO}_{2}-\mathrm{C} \overline{\mathrm{v}} \mathrm{O}_{2}\right) \text {. }
$$

Similarly, the coefficient of oxygen delivery for the brain can be expressed as:

coefficient of oxygen delivery (brain)

$=$ cerebral blood flow $\times \mathrm{CaO}_{2} / \mathrm{Vo}_{2}$ (brain)

$=\mathrm{CaO}_{2} /\left(\mathrm{CaO}_{2}-\mathrm{CjO}_{2}\right)$,

where $\mathrm{CaO}_{2}, \mathrm{C} \overline{\mathrm{v}} \mathrm{o}_{2}$, and $\mathrm{CjO}_{2}$ represent arterial, mixed venous, and internal jugular venous oxygen content $\left(\mathrm{Co}_{2}\right)$, respectively. Similarly, the suffixes "a," " $\bar{v}$," and " $\mathrm{j}$," with $\mathrm{Po}_{2}, \mathrm{So}_{2}$ and $\mathrm{pH}$, represent "arterial," "mixed venous" and "internal jugular venous" $\mathrm{Po}_{2}, \mathrm{So}_{2}$, and $\mathrm{pH}$ respectively. Extravascular oxygen supply is determined solely by physical diffusion and will therefore be dependent on the driving pressure of the oxygen, as well as on the geometry of the microvasculature and tissue. In this respect, venous $\mathrm{PO}_{2}$ is a useful guide to approximate mean tissue $\mathrm{Po}_{2}$, ${ }^{11}$ which is a statistical abstraction that represents an overall index of the state of tissue oxygenation.

\section{EXPERIMENTAL PROTOCOI}

Subjects were instructed to refrain from drinking coffee, tea, or caffeinated beverages on the day of the study and all medications were restricted from the day before. They were all in a clinically stable condition. For both studies, the subjects were placed in a supine position with their eyes closed.

\section{STUDY 1}

Subjects spontaneously breathed room air throughout the study. When the subject had had a stable heart rate and arterial pressure for at least 10 minutes, haemodynamic variables were measured, after which blood samples were collected simultaneously from the three lines (systemic artery, internal jugular vein, and main pulmonary artery). After this, a loading dose of aminophylline $(6 \mathrm{mg} / \mathrm{kg}$ body weight) ${ }^{12}$ was infused for 10 to 15 minutes. Fifteen minutes after the infusion, haemodynamic variables and blood samples were obtained again for comparison. Plasma theophylline concentrations were measured in four subjects at this time to ascertain that therapeutic concentrations $(10-20 \mathrm{mg} / \mathrm{l})$ were achieved.

\section{STUDY 2}

The subject breathed spontaneously through a mouthpiece connected to a J-valve. The $\mathrm{PaO}_{2}$ and $\mathrm{PaCO}_{2}$ were independently controlled by a 
Table 2 Effect of aminophylline on blood gases, oxygen transport, and haemodynamics in patients with chronic obstructive lung disease

\begin{tabular}{|c|c|c|}
\hline & $\begin{array}{l}\text { Control }(n=10) \\
\text { Mean }(S D)\end{array}$ & $\begin{array}{l}\text { Aminophylline } \\
(n=10) \\
\text { Mean }(S D)\end{array}$ \\
\hline $\mathrm{PaO}_{2}(\mathrm{~mm} \mathrm{Hg})$ & $73(10)$ & $73(10)$ \\
\hline $\mathrm{PjO}_{2}(\mathrm{~mm} \mathrm{Hg})$ & $35(7)$ & $29(6)^{\star \star}$ \\
\hline $\mathrm{P}^{\mathrm{v}} \mathrm{O}_{2}(\mathrm{~mm} \mathrm{Hg})$ & $37(3)$ & $35(3) \star \star$ \\
\hline $\mathrm{SaO}_{2}(\%)$ & $94(2)$ & $94(2)$ \\
\hline $\mathrm{SjO}_{2}(\%)$ & $61(13)$ & $50(13)^{\star \star}$ \\
\hline $\mathrm{Sv}_{2}(\%)$ & $68(4)$ & $66(5)^{\star}$ \\
\hline $\mathrm{CaO}_{2}(\mathrm{ml} / 100 \mathrm{ml})$ & $17 \cdot 2(2 \cdot 6)$ & $17 \cdot 3(2 \cdot 6)$ \\
\hline $\mathrm{CjO}_{2}(\mathrm{ml} / 100 \mathrm{ml})$ & $11 \cdot 1(3 \cdot 6)$ & $9 \cdot 2(3 \cdot 4)^{\star \star}$ \\
\hline $\mathrm{Cvo}_{2}(\mathrm{ml} / 100 \mathrm{ml})$ & $12 \cdot 4(2 \cdot 2)$ & $12 \cdot 0(2 \cdot 2)^{\star}$ \\
\hline $\mathrm{CaO}_{2}-\mathrm{CjO}_{2}(\mathrm{ml} / 100 \mathrm{ml})$ & $6 \cdot 1(2 \cdot 2)$ & $8 \cdot 1(2 \cdot 3)^{\star \star}$ \\
\hline $\left.\mathrm{CaO}_{2}-\mathrm{Cv}_{2} \mathrm{ml} / 100 \mathrm{ml}\right)$ & $4.9(0.9)$ & $5 \cdot 3(1 \cdot 1)^{\star \star}$ \\
\hline $\mathrm{CoD} j$ & $3.5(2.4)$ & $2 \cdot 5(1 \cdot 6)^{\star \star}$ \\
\hline $\mathrm{CoD} \overline{\mathrm{v}}$ & $3.6(0.6)$ & $3 \cdot 4(0 \cdot 6)^{\star \star}$ \\
\hline $\mathrm{pHa}$ & $7.42(0.04)$ & $7.44(0.04)^{\star \star}$ \\
\hline $\mathrm{pHj}$ & $7.37(0.04)$ & $7.38(0.03)$ \\
\hline $\mathrm{pH} \overline{\mathbf{v}}$ & $7.40(0.04)$ & $7.41(0.03)^{\star \star}$ \\
\hline $\mathrm{PaCO}_{2}(\mathrm{~mm} \mathrm{Hg})$ & $41(4)$ & $38(4)^{\star \star}$ \\
\hline $\mathrm{PjCO}_{2}(\mathrm{~mm} \mathrm{Hg})$ & $48(5)$ & $49(4)$ \\
\hline $\mathrm{P}^{\bar{v}} \mathrm{CO}_{2}(\mathrm{~mm} \mathrm{Hg})$ & $45(5)$ & $43(4)^{\star \star}$ \\
\hline Mean AP (mm Hg) & $92(13)$ & $89(13)$ \\
\hline Cardiac output (1/min) & $4 \cdot 3(1 \cdot 0)$ & $4.5(1 \cdot 0)$ \\
\hline Mean PAP $(\mathrm{mm} \mathrm{Hg})$ & $18(4)$ & $15(3)^{\star \star}$ \\
\hline
\end{tabular}

${ }^{\star} \mathrm{p}<0.05 ;{ }^{\star \star} \mathrm{p}<0.01$ compared with control data.

$\mathrm{CoDj}$-coefficient of oxygen delivery for the brain; $\mathrm{CoD} \overline{\mathrm{v}}$ -coefficient of oxygen delivery for the whole body; AParterial pressure; PAP-pulmonary arterial pressure; for other definitions see text.

$10 \mathrm{~mm} \mathrm{Hg}=1.33 \mathrm{kPa}$

dual control system. The system utilised end tidal $\mathrm{PO}_{2}\left(\mathrm{PETO}_{2}\right)$ and $\mathrm{PCO}_{2}\left(\mathrm{PETCO}_{2}\right)$ to regulate $\mathrm{PaO}_{2}$ and $\mathrm{PaCO}_{2}$ automatically and simultaneously by changing inspiratory gas composition. Details of the system are described elsewhere. ${ }^{1314}$ Respiratory gases were monitored by a mass spectrometer (Medical Gas Analyzer MGA-1100; Perkin-Elmer). Once the subject had breathed room air steadily for at least 10 minutes, arterial and jugular venous blood samples were taken simultaneously. PETO $_{2}$, controlled by the dual control system, was first increased to over $120 \mathrm{~mm} \mathrm{Hg}$ to maintain normoxaemia and kept there for the next five minutes. Blood samples were collected at the end of the normoxic period. The inspired oxygen concentration was then progressively lowered to levels of mild hypoxaemia $\left(\mathrm{PaO}_{2}\right.$ $60 \mathrm{~mm} \mathrm{Hg})^{\star}$ and severe hypoxaemia $\left(\mathrm{PaO}_{2}\right.$ $45 \mathrm{~mm} \mathrm{Hg}$ ) and sustained at each level for at

$10 \mathrm{~mm} \mathrm{Hg}=1.33 \mathrm{kPa}$.

Table 3 Blood gases and oxygen transport during room atr breathing, normoxia, mild hypoxia, and severe hypoxia in patients with chronic obstructive lung disease

\begin{tabular}{|c|c|c|c|c|}
\hline & $\begin{array}{l}\text { Room air } \\
(n=12) \\
\text { Mean }(S D)\end{array}$ & $\begin{array}{l}\text { Normoxia } \\
(n=12) \\
\text { Mean }(S D)\end{array}$ & $\begin{array}{l}\text { Mild hypoxia } \\
(n=8) \\
\text { Mean }(S D)\end{array}$ & $\begin{array}{l}\text { Severe hypoxia } \\
(n=12) \\
\text { Mean }(S D)\end{array}$ \\
\hline $\begin{array}{l}\mathrm{PaO}_{2}(\mathrm{~mm} \mathrm{Hg}) \\
\mathrm{PjO}_{2}(\mathrm{~mm} \mathrm{Hg}) \\
\mathrm{SaO}_{2}(\%) \\
\mathrm{SjO}_{2}(\%) \\
\mathrm{CaO}_{2}(\mathrm{ml} / 100 \mathrm{ml}) \\
\mathrm{CjO}_{2}(\mathrm{ml} / 100 \mathrm{ml}) \\
\mathrm{CODj} \\
\mathrm{pHa} \\
\mathrm{pH} \mathrm{H} \\
\mathrm{PaCO}_{2}(\mathrm{~mm} \mathrm{Hg}) \\
\mathrm{PicO}(\mathrm{mm} \mathrm{Ho})\end{array}$ & $\begin{array}{l}73(7) \\
35(4) \\
94(2) \\
64(7) \\
18 \cdot 4(2 \cdot 2) \\
12 \cdot 5(1 \cdot 9) \\
3 \cdot 3(1 \cdot 2) \\
7 \cdot 39(0 \cdot 02) \\
7 \cdot 36(0.02) \\
42(4) \\
48(5)\end{array}$ & $\begin{array}{l}103(20)^{\star \star} \\
38(3) \\
97(1)^{\star \star} \\
67(5) \\
19 \cdot 4(2 \cdot 2)^{\star \star} \\
13.3(1.7) \\
3.3(0.7) \\
7.39(0.03) \\
7.35(0.03) \\
42(4) \\
50(5)\end{array}$ & $\begin{array}{l}59(6)^{\star \star} \\
34(3) \\
91(2)^{\star} \\
62(6) \\
17 \cdot 7(2 \cdot 2)^{\star} \\
12 \cdot 1(2.0) \\
3 \cdot 3(0 \cdot 7) \\
7 \cdot 41(0.03)^{\star} \\
7 \cdot 37(0.02)^{\star} \\
39(3) \\
46(3)^{\star}\end{array}$ & $\begin{array}{l}45(4)^{\star \star} \\
30(2)^{\star \star} \\
82(4)^{\star \star} \\
54(6)^{\star \star} \\
16 \cdot 0(2 \cdot 3)^{\star \star} \\
10 \cdot 4(1 \cdot 9)^{\star \star} \\
2 \cdot 9(0 \cdot 4) \\
7 \cdot 43(0 \cdot 02)^{\star \star} \\
7 \cdot 38(0 \cdot 02)^{\star \star} \\
38(3)^{\star \star} \\
46(4)^{\star \star}\end{array}$ \\
\hline
\end{tabular}

$\star p<0.05 ;{ }^{\star \star} p<0.01$ compared with data obtained while breathing room air. For definitions see table 2 and text.

$10 \mathrm{~mm} \mathrm{Hg}=1.33 \mathrm{kPa}$. least five minutes. Blood samples were collected at the end of each period of hypoxia. In four out of 12 subjects we did not obtain blood samples during mild hypoxaemia. During the hypoxic challenge an attempt was made to maintain $\mathrm{PETCO}_{2}$ at the baseline level in each subject.

\section{STATISTICAL ANALYSIS}

Comparisions before and after aminophylline infusions were made with Student's paired $t$ test. Changes of variables in three or four series of measurements in the second study were assessed by analysis of variance (ANOVA) for repeated measurements. Mean values in the first and second studies were compared with Student's unpaired $t$ test. p values below 0.05 were accepted as significant.

\section{Results}

Study 1

Table 2 shows the data obtained in the first study. The most striking results were pronounced falls in $\mathrm{PjO}_{2}$ and $\mathrm{SjO}_{2}$ after the aminophylline infusion (from 35 (SD 7) $\mathrm{mm} \mathrm{Hg}$ and $61(13) \%$ to 29 (6) $\mathrm{mm} \mathrm{Hg}$ and 50 (13)\% respectively), whereas $\mathrm{PaO}_{2}$ and $\mathrm{SaO}_{2}$ remained constant or actually increased in some cases and $\mathrm{P} \mathrm{vO}_{2}$ and $\mathrm{Svv}_{2}$ showed only small decreases (from 37 (3) $\mathrm{mm} \mathrm{Hg}$ and $68(4) \%$ to $35(7) \mathrm{mm}$ $\mathrm{Hg}$ and 66 (5)\% respectively). As anticipated there was a decrease in $\mathrm{PaCO}_{2}$ by $2.7 \mathrm{~mm} \mathrm{Hg}$ and an associated increase in arterial $\mathrm{pH}$ by 0.01 that reflected increased minute ventilation caused by aminophylline. Neither $\mathrm{PCO}_{2}$ nor pHj changed significantly, however. No significant changes occurred in mean systemic arterial pressure or cardiac output, whereas mean pulmonary arterial pressure showed the expected decrease from 18 (4) to 15 (3) $\mathrm{mm} \mathrm{Hg}$. Although the arteriovenous difference in calculated oxygen content increased significantly both in the cerebral circulation and in the whole body after the aminophylline infusion, the change in the first was about five times greater than that in the second $(2.0 v 0.4 \mathrm{ml} /$ $100 \mathrm{ml}$ ). Similarly, the decrease in the coefficient of oxygen delivery with aminophylline was greater for the brain (from $3.5(2.4)$ to 2.5 $(1 \cdot 6)$ ) than for the whole body (from $3 \cdot 6(0 \cdot 6)$ to $3.4(0 \cdot 6))$. The mean plasma theophylline concentration measured in four subjects $15 \mathrm{~min}$ utes after the aminophylline infusion was 14.1 (2.7) $\mathrm{mg} / \mathrm{l}$.

\section{Study 2}

Table 3 presents the data obtained in the second study. Despite attempts to maintain isocapnia during hypoxic challenge, $\mathrm{PaCO}_{2}$ decreased significantly from 42 (4) $\mathrm{mm} \mathrm{Hg}$ while breathing room air to 38 (3) $\mathrm{mm} \mathrm{Hg}$ during severe hypoxia. This was because we wanted to avoid any overcorrection for $\mathrm{PaCO}_{2}$ in this study. Thus $\mathrm{PaCO}_{2}$ fell by $3.8 \mathrm{~mm} \mathrm{Hg}$ from the control value on average during severe hypoxia, which was comparable with the change in $\mathrm{PaCO}_{2}$ after the aminophylline infusion in the first study. Whereas the mean $\mathrm{PaO}_{2}$ varied from $103(20)$ at normoxia to $45(4)$ $\mathrm{mm} \mathrm{Hg}$ during severe hypoxia, the corresponding mean $\mathrm{PjO}_{2}$ decreased from 38 (3) to 30 (2) 


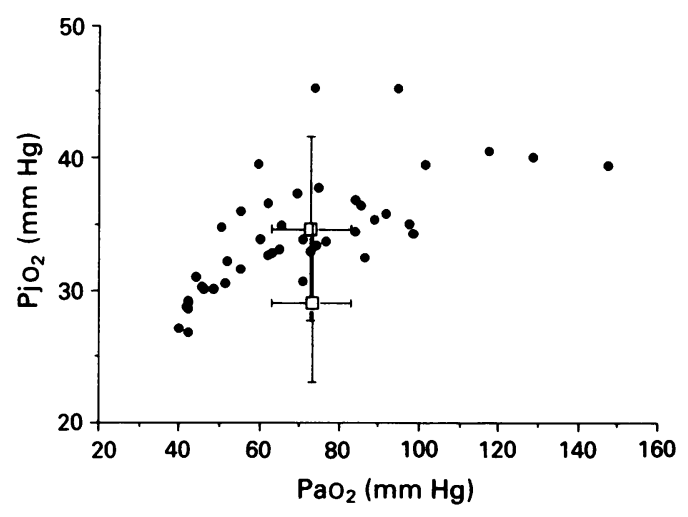

Pooled data of jugular venous $\mathrm{Po}_{2}\left(\mathrm{PjO}_{2}\right)$ as a function of $\mathrm{PaO}_{2}$ in 12 patients with chronic obstructive lung disease. $\mathrm{PaCO}_{2}$ varied from 42 (SD4) $\mathrm{mm} \mathrm{Hg}$ during the breathing of room air to 38 (3) $\mathrm{mm} \mathrm{Hg}$ during severe hypoxia. The data (means and $\mathrm{SD}$ ) for $\mathrm{PaO}_{2}$ and $\mathrm{PjO}_{2}$, before and after aminophylline infusion, were obtained in another experiment with a different group of patients $(n=10)$. Upper: before aminophylline infusion; lower: after aminophylline infusion. See text for details. $10 \mathrm{~mm} \mathrm{Hg}=1.33 \mathrm{kPA}$.

$\mathrm{mm} \mathrm{Hg}$. The figure (pooled data from 12 subjects) show the curvilinear relation between $\mathrm{PaO}_{2}$ and $\mathrm{PjO}_{2}$. The mean values of $\mathrm{PaO}_{2}$ and $\mathrm{PjO}_{2}$ before and after the aminophylline infusion obtained in the first study are both plotted on the same figure to show the differential effect of aminophylline on $\mathrm{PaO}_{2}$ and $\mathrm{PjO}_{2}$. The mean values of $\mathrm{PjO}_{2}$ and $\mathrm{Sjo}_{2}(29$ (6) mm $\mathrm{Hg}$ and $50(13) \%$ obtained after aminophylline infusion in the first study were similar to those obtained during severe hypoxia in the second study (30 (2) $\mathrm{mm} \mathrm{Hg}$ and $54(6) \%$ ) at the same level of $\mathrm{PaCO}_{2}(38$ (4) $v 38$ (3) $\mathrm{mm} \mathrm{Hg}$ ) on two occasions (tables 2 and 3 ). The coefficient of oxygen delivery to the brain did not significantly change even during severe hypoxia.

\section{Discussion}

The present studies show that, in mildly hypoxaemic patients with chronic obstructive lung disease $\left(\mathrm{PaO}_{2} 73 \mathrm{~mm} \mathrm{Hg}\right)$, a clinically relevant dose of aminophylline caused the $\mathrm{PjO}_{2}$ and $\mathrm{SjO}_{2}$ to decrease in the presence of an unchanged $\mathrm{PaO}_{2}$. Also the values of $\mathrm{PjO}_{2}$ and $\mathrm{SiO}_{2}$ measured after an aminophylline infusion in these subjects were similar to the measurements made under conditions of severe arterial hypoxaemia $\left(\mathrm{PaO}_{2} 45 \mathrm{~mm} \mathrm{Hg}\right)$ and similar $\mathrm{PaCO}_{2}$ in another group of patients. If we accept that venous $\mathrm{Po}_{2}$ reflects the average tissue $\mathrm{Po}_{2}$, these results suggest that aminophylline administration reduces brain tissue $\mathrm{Po}_{2}$ as much as severe arterial hypoxaemia. Moreover, this effect of aminophylline seems specific to the brain because $\mathrm{P}_{\bar{v}} \mathrm{O}_{2}$ and $\mathrm{Sv}_{2}$ showed only small decreases compared with the considerable falls in $\mathrm{PjO}_{2}$ and $\mathrm{SjO}_{2}$.

There are at least two possible explanations for the dramatic effect of aminophylline on $\mathrm{PjO}_{2}$ and $\mathrm{SjO}_{2}$ with only small changes in $\mathrm{Pvo}_{2}$ and $\mathrm{S}^{-} \mathrm{O}_{2}$. They are, firstly, a selective decrease in cerebral blood flow with a compensatory increase in oxygen extraction and, secondly, an increase in the metabolic rate for oxygen only in the brain. Because we unfortunately did not measure changes in cerebral blood flow, the second mechanism might have been a contributing factor. Several studies have shown that theophylline significantly reduces cerebral blood flow in humans, however, ${ }^{5-8}$ including patients with chronic obstructive lung disease. Its effect is now thought to be largely due to adenosine receptor blockade ${ }^{15}$ and partly due to a small decrease in $\mathrm{PaCO}_{2}$ as a consequence of increased ventilation, as was shown in our study.

For these conclusions to be valid, it must be assumed that blood collected from the internal jugular vein truly represents mixed cerebral venous blood. As there are several emissary veins or communications between the cerebral and extracerebral drainage systems in the internal jugular vein, the ideal sampling site is cephalad to the superior jugular bulb. Early studies by Kety and Schmidt ${ }^{16}$ have shown that, in most subjects, blood from the internal jugular vein at the level of the superior bulb is representative of mixed cerebral venous blood not appreciably contaminated with blood from extracranial sources, although there still might be about $5 \%$ of extracranial contamination error. The sampling technique in the current study was not one with direct puncture of the jugular bulb, which was used in most early studies ${ }^{17}$ but is now considered ethically unacceptable. We inserted the catheter tip as close as possible to the jugular bulb, however, as we advanced it $4 \mathrm{~cm}$ from the puncture site. The data on arteriojugular venous oxygen content difference obtained in our present study $(6 \cdot 1$ $(2 \cdot 2)$ vol $\%$ ) was similar to those obtained in two previous studies, ${ }^{56}$ by the direct sampling method (6.7 (1.4), $6.3(1.2)$ vol\%), suggesting that the blood samples we obtained reflected mixed cerebral venous blood. Also, with the current sampling method, we have successfully shown previously that $\mathrm{PjCO}_{2}$ decreases significantly during isocapnic hypoxic challenge in healthy subjects as a result of hypoxia induced cerebral vasodilation, which does not occur in the extracerebral circulation. ${ }^{14} 18$

The low level of $\mathrm{PjO}_{2}$ or $\mathrm{SjO}_{2}$ obtained with aminophylline infusion does not imply brain tissue hypoxia. The decrease in $\mathrm{PjO}_{2}$ or $\mathrm{SjO}_{2}$ shown in this study may represent increased oxygen extraction with normal oxygen metabolism and thus no brain tissue hypoxia. The effect of longer periods of mild to moderate hypoxia on brain dysfunction, however, is well recognised. ${ }^{19}$ It has been suggested that the metabolism of several neurotransmitters or neuromodulators, including acetylcholine, is altered by mild hypoxia even when the supply for the brain is not impaired. ${ }^{20}$ Changes in amino acid concentrations in the brain have been reported during moderate hypoxia. ${ }^{21}$ These include increases in alanine, glutamine, and $\delta$-aminobutyric acid and decreases in aspartate and glutamate. Also chronic mild to moderate hypoxia may be an important factor in the impaired neuropsychological function reported in patients with chronic obstructive lung disease. ${ }^{34}$ The possibility cannot be ruled out, therefore, that the level of brain tissue $\mathrm{PO}_{2}$. 
during aminophylline infusion might be low enough to cause some brain dysfunction.

In general, the roles of oxygen transport within the vascular system and oxygen pressure in the extravascular compartment jointly contribute to oxygen supply by a mixture that is either convection or diffusion limited. ${ }^{1022}$ In the second study, the coefficient of oxygen delivery for the brain, which is thought to reflect the convection process, was not significantly changed during severe hypoxaemia, probably due to a compensatory increase in cerebral blood flow as a result of hypoxia induced cerebral vasodilation. On the other hand, the coefficient of oxygen delivery for the brain showed a significant decrease after the aminophylline infusion. Thus whether due to the convection or the diffusion process, aminophylline given to even mildly hypoxaemic subjects has disadvantages for the brain, which may worsen during severe hypoxaemia.

In summary, the present study suggests that a therapeutic dose of aminophylline, given to mildly hypoxaemic (mean $\mathrm{PaO}_{2} 73 \mathrm{~mm} \mathrm{Hg}$ ) patients with chronic obstructive lung disease, reduces brain tissue $\mathrm{Po}_{2}$ to a similar degree to that caused by severe arterial hypoxaemia (mean $\mathrm{PaO}_{2} 45 \mathrm{~mm} \mathrm{Hg}$ ). Although this study does not provide firm evidence that aminophylline itself causes brain hypoxia, the drug may be harmful if there are coexisting factors such as hypocapnia reducing cerebral blood flow, or severe hypoxia that reduces the reserve capacity of the cerebral circulation to cope with metabolic stress. The balance of therapeutic advantage will certainly depend on whether the improvement in oxygenation resulting from the bronchodilator and other effects of aminophylline outweighs its disadvantages. The effects of chronic administration of theophylline on brain tissue $\mathrm{PO}_{2}$ remain to be evaluated.

1 Rachelefsky GS, Wo J, Adelson J, Mickey MR, Spector SL, Katz RM, et al. Behavior abnormalities and poor school performance due to oral theophylline use. Pediatrics 1986;78:1133-8.

2 Furukawa CT, DuHamel TR, Weimer L, Shapiro GG, Pierson WE, Bierman CW. Cognitive and behavioral findings in children taking theophylline. $J$ Allergy Clin findings in children tak

3 Grant I, Heaton RK, McSweeny AJ, Adams KM, Timms RM. Neuropsychologic findings in hypoxemix chronic obstructive pulmonary disease. Arch Intern Med 1982;142:1470-6.
4 Prigatano GP, Parsons OA, Wright EC, Levin DC, Hawryluk G. Neuropsychological test performance in mildly hypoxemic patients with chronic obstructive pulmonary disease. J Consult Clin Psychol 1983;51: 108-16.

5 Wechsler RL, Kleiss LM, Kety SS. The effects of intravenously administered aminophylline on cerebral circulation and metabolism in man. $J$ Clin Invest 1950;29:28-30.

6 Moyer JH, Tashnek AB, Miller SI, Snyder H, Bowman OR. The effect of theophylline with ethylenediamine (aminophylline) and caffeine on cerebral hemodynamics and cerebrospinal fluid pressure in patients with hypertensive headaches. Am J Med Sci 1952;224:377-85.

7 Gottstein U, Held K, Sebening H, Steiner K. Is decrease of cerebral blood flow after intravenous injections of theophylline due to direct vasoconstrictive action of the drug? Eur Neurol 1971/2;6:153-7.

8 Magnussen IB, Høedt-Rasmussen KJA. The effect of intraarterial administered aminophylline on cerebral hemodynamics in man. Acta Neurol Scand 1977;55:131-6.

9 Bowton DL, Alford PT, McLees BD, Prough DS, Stump DA. The effect of aminophylline on cerebral blood flow in patients with chronic obstructive pulmonary disease. Chest 1987;91:874-7.

10 Tenney SM, Mithoefer JC. The relationship of mixed venous oxygenation to oxygen transport: with special reference to adaptations to high altitude and pulmonary disease. Am Rev Respir Dis 1982;125:474-9.

11 Tenney SM. A theoretical analysis of the relationship between venous blood and mean tissue oxygen pressures. Respir Physiol 1974;20:283-96.

12 Paterson JW, Woolcock AJ, Shenfield GM. Bronchodilator drugs. Am Rev Respir Dis 1979;120:1149-88

13 Kawakami Y, Asanuma Y, Yosikawa T, Murao M. A control system for arterial blood gases. J Appl Physiol 1981;50:1362-6.

14 Nishimura $M$, Suzuki A, Nishiura $Y$, Yamamoto $H$, Miyamoto K, Kishi F, et al. Effect of brain blood flow on hypoxic ventilatory response in humans. $J$ Appl Physiol 1987;63:1100-6.

15 Morii S, Ngal AC, Ko KR, Winn HR. Role of adenosine in regulation of cerebral blood flow: effects of theophylline during normoxia and hypoxia. Am $J$ Physiol during normoxia

16 Kety SS, Schmidt CF. The nitrous oxide method for the quantitative determination of cerebral blood flow in man: Theory, procedure and normal values. J Clin Invest 1948;27:476-83.

17 Gibbs EL, Lennox WG, Gibbs FA. Bilateral internal jugular blood: comparison of A-V differences, oxygendextrose ratios and respiratory quotients. Am J Psychiatry 1945;102:184-90.

18 Suzuki A, Nishimura M, Akiyama Y, Kishi F, Kawakami Y. No effect of brain blood flow on ventilatory depression during sustained hypoxia. J Appl Physiol 1989;66: 1674-8.

19 Gibson GE, Pulsinelli W, Blass JP, Duffy TS. Brain Dysfunction in mild to moderate hypoxia. Am J Med 1981;70:1247-54.

20 Gibson GE, Duffy TE. Impaired synthesis of acetylcholine by mild hypoxic hypoxia or nitrous oxide. $J$ Neurochem 1981;36:28-33.

21 Siesjo BK, Ingvar M. Ventilation and brain metabolism. In: Cherniack NS, Widdicombe G, eds. Handbook of physiology. Section 3: the respiratory system. Vol II, control physiology. Section 3: the respiratory system. Vol II, control of breathing, par

22 Kawakami Y, Kishi F, Yamamoto H, Miyamoto K. Relation of oxygen delivery, mixed venous oxygenation and pulmonary hemodynamics to prognosis in chronic obstructive pulmonary disease. $N$ Engl J Med 1983;308:1045-9. 